ISSN : 2615-1995, E-ISSN : 2615-0654

J. Madani., Vol. 4, No. 1, Maret 2021 (51 - 60)

(C)2018 Lembaga Kajian Demokrasi

MADANI

dan Pemberdayaan Masyarakat (LKD-PM)

DOI: https://doi.org/10.33753/madani.v4i1.152

\title{
Analisis Pengaruh Kualitas Akrual, Persistensi Laba, dan Perataan Laba Terhadap Informasi Asimetri
}

\author{
Asih Handayani \\ Fakultas Ekonomi, Universitas Pamulang \\ asih.handayani52@gmail.com
}

\begin{abstract}
Abstrak
Penelitian ini bertujuan untuk menguji pengaruh kualitas akrual, persistensi laba dan perataan laba terhadap informasi asimetri. Pendekatan penelitian yang digunakan pada penelitian ini yaitu kuantitatif asosiatif. Yang merupakan penelitian dengan tujuan untuk mengetahui pengaruh ataupun juga hubungan antara dua variabel atau lebih secara sistematis, terencana dan terstruktur dengan jelas sejak awal. Populasi dalam penelitian ini sebanyak 17 perusahaan manufaktur subsektor tekstil dan garment., dengan menggunakan data skunder tahun 2011-2015. Teknik pengambilan sampel dengan menggunakan tekniki purposive sampling sehingga dihasilkan jumlah sampel sebanyak 9 perusahaan dengan total observasi 45 laporan keuangan perusahaan Teknik analisis data yang digunakan dalam penelitian ini adalah regresi panel. Pada penelitian ini membuktikan hasil penelitian bahwa kualitas akrual tidak berpengaruh terhadap informasi asimetri; juga membuktikan bahwa persistensi laba tidak memiliki pengaruh signifikan terhadap informasi asimetri. Sedangkan perataan laba memiliki pengaruh signifikan terhadap informasi asimetri. Dan secara simultan kualitas akrual, persistensi laba dan perataan laba secara bersama-sama berpengaruh namun sangat lemah terhadap informasi asimet. Sehingga dapat disimpulkan bahwa hasil penelitian ini menunjukkan variabel kualitas akrual dan persistensi laba tidak memiliki pengaruh yang signifikan terhadap informasi asimetri sedangkan perataan laba berpengaruh negatif signifikan terhadap informasi asimetri yang berarti semakin kecil perusahaan melakukan perataan laba semakin besar kemungkinan adanya informasi asimetri.
\end{abstract}

Kata Kunci : Kualitas Akrual, Persistensi Laba, Perataan Laba, Informasi Asimetri

\section{Abstract}

This study aims to test the influence of accrual quality, profit persistence and profit leveling on asymmetry information. The research approach used in this study is quantitative associative. Which is a research with the aim to know the influence or also the relationship between two or more variables systematically, planned and structured clearly from the beginning. The population in this study was 17 textile and garment subsector manufacturing companies, using subsisting data from 2011-2015. Sampling techniques using purposive sampling techniques resulting in the number of samples as many as 9 companies with a total observation of 45 financial statements of the company Data analysis techniques used in this study is a regression panel. This study proves that accrual quality has no effect on asymmetry information it also proves that profit persistence has no significant influence on asymmetry information. Meanwhile, profit leveling has a significant influence on asymmetry information. And simultaneously thequality of accruals, the persistence of profit and the 
flattening of profits are jointly influential but very weak to the information asimet. So, it can be concluded that the results of this study showed the variable quality of accrual and persistence of profit does not have a significant influence on asymmetry information while profit leveling has a significant negative effect on asymmetry information which means that the smaller the company performs profit leveling the more likely it is to have asymmetry information

Keywords : Accrual Quality, Profit Persistence, Profit Alignment, Asymmetry Information

\section{PENDAHULUAN}

Di era digital saat ini, dimana segala informasi dapat diakses dengan mudah melalui berbagai macam teknologi informasi kekinian menjadikan pengguna informasi harus semakin berhati-hati pada saat memahami informasi yang tersebar luas lewat media informasi manapun, baik media cetak maupun media internet. Salah satunya adalah informasi mengenai laporan keuangan sebuah perusahaan publik yang dipublikasikan melalui website perusahaan maupun melalui Bursa Efek Indonesia (BEI) yang dibutuhkan oleh para pemegang saham publik yang notabenenya bukan merupakan bagian dari manajemen perusahaan dan hanya sebagai investor bagi perusahaan tersebut.

Laporan keuangan merupakan alat komunikasi antara manajemen perusahaan dengan para stakeholder, dimana didalamnya terdapat informasi-informasi yang dibutuhkan oleh para investor untuk mengevaluasi dan membuat keputusan mengenai investasi yang dilakukannya. Adapun informasi yang dimaksud antara lain, seperti: kinerja perusahaan, kondisi keuangan perusahaan, arus kas perusahaan dan catatan-catatan penting lainnya yang tertuang dalam laporan keuangan perusahaan.

Apriliani (2012) mengemukakan bahwa informasi asimetri merupakan suatu keadaan dimana manajer memiliki akses informasi atas prospek perusahaan yang tidak dimiliki oleh pihak luar perusahaan. Jensen dan Meckling (1976) dalam Benardi et al. (2009) menyatakan bahwa hubungan keagenan muncul ketika satu atau lebih individu (principal) mempekerjakan individu lain (agent) untuk memberikan suatu jasa dan kemudian mendelegasikan kekuasaan kepada agent untuk membuat suatu keputusan atas nama principal tersebut, sebagai suatu kontrak antara manajer selaku agent dengan pemilik sebagai principal perusahaan.

Menurut Wisnumurti (2010) dalam Apriliani (2012) agent yang mengetahui informasi internal lebih banyak mengenai perusahaan dibandingkan dengan principal, harus memberikan informasi mengenai kondisi perusahaan kepada principal. Tetapi informasi yang disampaikan oleh manajer terkadang tidak sesuai dengan kondisi perusahaan yang sebenarnya karena manajer cenderung untuk melaporkan sesuatu yang memaksimalkan utilitasnya. Ujiyantho (2007) menambahkan asimetri informasi yang terjadi antara manajemen (agent) dengan pemilik (principal) memberikan kesempatan kepada manajer untuk bertindak oportunis, yaitu demi memperoleh keuntungan pribadi.

Menurut Suwardjono (2010) pengertian pelaporan keuangan adalah struktur dan proses akuntansi yang menggambarkan bagaimana informasi keuangan disediakan dan dilaporkan untuk mencapai tujuan ekonomik dan sosial negara. Fanani (2009) membagi pengertian kualitas pelaporan keuangan dalam dua sudut pandang. Pandangan pertama menyatakan bahwa kualitas pelaporan keuangan berhubungan dengan kinerja keseluruhan perusahaan yang tercermin dalam laba perusahaan. Pandangan ini menyatakan bahwa laba yang berkualitas tinggi terefleksikan pada laba yang berkesinambungan (sustainable) untuk suatu periode yang lama. Pandangan kedua menyatakan bahwa kualitas pelaporan keuangan berkaitan dengan kinerja pasar modal yang diwujudkan dalam bentuk imbalan, sehingga hubungan yang semakin kuat antara laba perusahaan dengan imbalan menunjukkan informasi pelaporan keuangan yang tinggi (Ayres, 1994 dalam Fanani, 2009).

Francis et al. (2004) membagi atribut kualitas pelaporan keuangan menjadi dua kelompok, yaitu atribut berbasis akuntansi dan atribut berbasis pasar untuk mengetahui perbedaan asumsi dari fungsi laba, dimana hal tersebut akan tercermin melalui cara pengukuran dari masing-masing atribut. Atribut berbasis akuntansi antara lain: kualitas akrual, persistensi, prediktabilitas dan perataan laba. Atribut ini hanya menggunakan informasi akuntansi saja seperti kas atau laba sebagai alat ukur untuk menilai kualitas suatu 
laporan keuangan. Sedangkan atribut berbasis pasar, antara lain: relevansi nilai, ketepatwaktuan dan konservatisme. Atribut ini diukur dengan estimasi hubungan antara laba akuntansi dan harga pasar saham atau return untuk menilai kualitas suatu laporan keuangan.

Verdi (2006) dalam Wijaya et al. (2010) menyatakan bahwakualitas laporankeuangan dapat dilihat dari kualitas akrual perusahaan. Kualitas laporan keuangan perusahaan dapat meningkatkan efisiensi investasi perusahaan melalui upaya untuk mengurangi asimetri informasi. Laporan keuangan yang berkualitas akan mengurangi asimetri informasi antara perusahaan dan investor, mengurangi biaya adverse selection dan biaya pendanaan perusahaan yang menjadi lebih rendah. Selain itu, laporan keuangan yang berkualitas akan mengurangi asimetri informasi antara investor dan manajer, mengurangi terjadinya agensi konflik, biaya pengawasan manajer yang lebih rendah dan meningkatkan pemilihan projek.

Teruel et al. (2009) dalam Wijaya et al. (2010) menyatakan bahwa kualitas akural adalah kualitas informasi akuntansi yang disajikan perusahaan yang membandingkan antara akrual dengan arus kas perusahaan pada periode masa lalu, sekarang dan masa depan. Kualitas akrual dikatakan baik jika akrual memiliki kedekatan dengan aliran arus kas perusahaan di masa depan (Dechow dan Dichev, 2002 dalam Wijaya et al., 2010).

Persistensi laba diartikan sebagai kemampuan laba suatu perusahaan untuk bertahan di masa depan (Penman, 2001 dalam Fitriana dan Fadhlia, 2016). Persistensi laba sering dianggap sebagai alat ukur untuk menilai kualitas laba yang berkesinambungan dan cenderung stabil atau tidak berfluktuasi di setiap periode (Purwanti, 2011 dalam Fitriana dan Fadhlia, 2016). Laba yang persisten merupakan laba yang cenderung tidak berfluktuatif dan mencerminkan keberlanjutan laba di masa depan dan berkesinambungan untuk periode yang lama (Fitriana dan Fadhlia, 2016).

Barnea et al., (1976) dalam Kurniawan (2014) mendefinisikan perataan laba sebagaipengurangan yang disengaja terhadap fluktuasi terhadap beberapa level laba agar dianggap normal bagi perusahaan. Presetio (2001) dalam Setyaningtyas dan Hadiprijanto (2014) menjelaskan bahwa perataan laba atau yang sering disebut dengan income smoothing tidak akan terjadi apabila laba yang dihasilkan oleh perusahaan tidak berbeda jauh dengan laba yang diharapkan. Hal tersebut menegaskan bahwa keputusan akan investasi dari pemegang saham sangat dipengaruhi dari laba perusahaan sehingga manajer selalu berusaha untuk memberikan informasi dengan sebaikbaiknya yang diharapkan dapat meningkatkan kepercayaan pemegang saham. Perataan laba (income smoothing) yang dilakukan oleh pihak manajemen akan sangat berpengaruh terhadap keputusan pemegang saham.

Informasi asimetri sendiri telah banyak diteliti di Indonesia seperti yang dilakukan oleh Husna dan dan Zulfikar (2017) menguji pengaruh atribut kualitas pelaporan keuangan terhadap informasi asimetri dengan hasil variabel relevansi nilai, ketepatwaktuan, konservatisme, kualitas akrual, dan perataan laba tidak berpengaruh terhadap informasi asimetri. Sedangkan variabel presistensi laba berpengaruh terhadap informasi asimetri.

Kusuma et al. (2014) dalam penelitiannya menguji pengaruh kualitas pelaporan keuangan dengan proksi relevansi nilai, kepemilikan institusional dan ukuran perusahaan terhadap asimetri informasi dengan hasil variabel kualitas pelaporan keuangan dan kepemilikan institusional tidak berpengaruh terhadap asimetri informasi sedangkan ukuran perusahaan berpengaruh terhadap asimetri informasi.

Setiany dan Wulandari (2015) meneliti tentang kualitas pelaporan keuangan dengan relevansi nilai dan asimetri informasi dengan hasil variabel relevansi nilai berpengaruh negatif signifikan terhadap informasi asimetri.

Dalam penelitian yang dilakukan Fanani (2009) tidak terjadi tumpang tindih antara atribut kualitas pelaporn keuangan satu sama lain. Selanjutnya dalam penelitian Fanani (2009) memberikan hasil kualitas pelaporan keuangan berpengaruh negatif dan signifikan terhadap informasi asimetri, dengan menggunakan kualitas pelaporan keuangan faktorial yang terdiri atas relevansi nilai dan konservatisme sebagai atribut kualitas pelaporan keuangannya.

Indriani dan Khoiriyah (2010) juga meneliti hal yang sama, dengan menggunakan atribut kualitas pelaporan sebagai variabel independen dan asimetri informasi sebagai variabel dependen. Indriani dan Khoiriyah (2010) menggunakan konsekuensi ekonomi dan model bid-ask spread sebagai proksi asimetri informasi dalam penelitiannya. Berbeda dengan penelitian sebelumnya, Indriani dan Khoriyah (2010) dalam penelitiannya menemukan bahwa adanya hubungan positif namun tidak signifikan antara kualitas pelaporan keuangan dan asimetri informasi. 
Asimetri informasi menjadi penting untuk diteliti dikarenakan masih banyaknya praktekpraktek kecurangan yang terjadi di perusahaan yang diakibatkan oleh adanya perbedaan informasi yang diperoleh antara para stakeholder, bisa dalam hal mengenai keuangan perusahaan, akuntansi dan pencatatan maupun hal-hal lainnya yang disembunyikan oleh manajemen perusahaan. Sudah banyak peneliti terdahulu yang meneliti tentang faktor-faktor yang menyebabkan terjadinya informasi asimetri, namun sampai saat ini hasilnya masih saja belum konsisten antara peniliti satu dengan lainnya, penulis berniat melakukan penelitian ini agar bisa dijadikan referensi tambahan sebagai pendukung maupun penguat dari penelitian-penelitian terdahulu.

Berdasarkan latar belakang di atas, penulis tertarik untuk menguji kembali kualitas akrual, persistensi laba dan perataan laba secara parsial dan bersama-sama mengenai pengaruhnya terhadap informasi asimetri. Perbedaan penelitian ini dengan penelitian sebelumnya terutama pada objek penelitiannya yang lebih up to date yaitu perusahaan manufaktur yang terdaftar di BEI periode 2011-2015. Adapun judul penelitian ini adalah "Analisis Pengaruh Atribut Kualitas Pelaporan Keuangan Terhadap Informasi Asimetri (Studi Empiris Pada Perusahaan Manufaktur Subsektor Tekstil dan Garment yang Terdaftar di Bursa Efek Indonesia Periode 2011-2015)".

\section{METODE}

\section{Jenis dan Pendekatan Penelitian}

Jenis penelitian yang digunakan dalam penelitian ini adalah kuantitatif dengan pendekatan asosiatif. Metode penelitian kuantitatif merupakan salah satu jenis penelitian yang spesifikasinya adalah sistematis, terencana dan terstruktur dengan jelas sejak awal hingga pembuatan desain penelitiannya. Definisi metode penelitian asosiatif menurut Sugiyono (2014) adalah penelitian yang bertujuan untuk mengetahui pengaruh ataupun juga hubungan antara dua variabel atau lebih.

\section{Populasi dan Sampel}

Populasi dalam penelitian ini merupakan seluruh perusahaan manufaktur sektor tekstil dan garment yang terdaftar di BEI periode 2011-2015 dan jumlah populasi dalam penelitian ini adalah 17 perusahaan. Alasan mengapa sektor manufaktur dijadikan populasi dalam penelitian ini adalah karena perusahaan manufaktur merupakan emiten terbesar yang terdaftar di BEI dan penulis ingin memusatkan penelitian pada perusahaan manufaktur sektor tekstil dan garment.

Sampel penelitian ini adalah perusahaan manufaktur sektor tekstil dan garment yang terdaftar di BEI, dipilih dengan menggunakan purposive sampling dengan kriteria sebagai berikut:

a. Perusahaan manufaktur sektor tekstil dan garment yang terdaftar di BEI selama periode 2011-2015.

b. Perusahaan manufaktur sektor tekstil dan garment yang tidak keluar selama periode pengamatan tahun 2011-2015.

c. Perusahaan manufaktur sektor tekstil dan garment yang menerbitkan dan menyajikan laporan keuangan lengkap sesuai data yang diperlukan dalam penelitian dan dalam mata uang dolar amerika serikat selama periode 2011-2015.

d. Perusahaan manufaktur sektor tekstil dan garment yang tidak melakukan akuisisi dan merger serta tidak mengalami perubahan sektor industri maupun perubahan nama selama periode 2011-2015.

Tabel 1 menunjukkan hasil seleksi sampel penelitian.

Tabel 1. Hasil Seleksi Sampel Penelitian

\begin{tabular}{lc}
\hline \multicolumn{1}{c}{ Keterangan } & \multicolumn{1}{c}{ Jumlah } \\
\hline Jumlah Sampel Awal & 17 Perusahaan \\
Perusahaan manufaktur sektor & \\
tekstil dan garment yang terdaftar di & 17 Perusahaan \\
BEI selama periode 2011-2015 & \\
Perusahaan manufaktur sektor & \\
tekstil dan garment yang tidak & 17 Perusahaan \\
keluar selama periode pengamatan & \\
tahun 2011-2015 & \\
$\begin{array}{l}\text { Perusahaan manufaktur sektor } \\
\text { tekstil dan garment yang }\end{array}$ & \\
menerbitkan dan menyajikan & \\
laporan keuangan lengkap sesuai \\
data yang diperlukan dalam & 9 Perusahaan \\
penelitian selama periode 2011- & \\
2015 & \\
$\begin{array}{l}\text { Perusahaan manufaktur sektor } \\
\text { tekstil dan garment yang tidak } \\
\text { melakukan akuisisi dan merger serta }\end{array}$ & \\
tidak mengalami perubahan sektor \\
industri maupun perubahan nama \\
selama periode 2011-2015
\end{tabular}




\section{Operasionalisasi Variabel Peneliatan}

Subjek penelitian ini adalah perusahaan manufaktur. Data-data yang digunakan meliputi laporan keuangan periode 2011-2015, gambaran umum perusahaan dan data lain yang dibutuhkan dalam penelitian. Variabel independen terdiri dari kualitas akrual, persistensi laba, prediktabilitas laba, perataan laba, relevansi nilai, ketepatwaktuan dan konservatisme; variabel dependen, yaitu informasi asimetri. Definisi operasional variabel-variabel dalam penelitian ini adalah sebagai berikut:

\section{Kualitas Akrual}

Teruel et al. (2009) dalam Wijaya et al. (2010) menyatakan bahwa kualitas akrual adalah kualitas informasi akuntansi yang disajikan perusahaan yang membandingkan antara akrual dengan arus kas perusahaan pada periode masa lalu, sekarang dan masa depan. Kualitas akrual dikatakan baik jika akrual memiliki kedekatan dengan aliran kas perusahaan di masa depan (Dechow dan Dichev, 2002 dalam Wjiaya et al, (2010).

Pengukuran kualitas akrual dalam penelitian ini menggunakan pendekatan accruals-cash flow mengacu Dechow dan Dichev (2002) serta Francis et al. (2008).

$\mathrm{WCA}=\alpha+\beta 1$ CFOt $-1+\beta 2 \mathrm{CFOt}+\beta 3 \mathrm{CFOt}+1$ $+\beta 4 \triangle R E V+\beta 5 P P E+\varepsilon$

Di mana:

WCA (Working Current Accrual) $=\Delta$ Aktiva Lancar - $\Delta$ Utang Lancar $-\Delta$ Kas dan Setara Kas)

$\Delta$ Aktiva Lancar $=$ Aktiva Lancar $(\mathrm{t})-$ Aktiva Lancar (t-1)

$\Delta$ Utang lancar $=$ Utang lancar $(\mathrm{t})-$ Utang lancar (t-1)

$\Delta$ Kas dan Setara Kas $=$ Kas dan Setara Kas $(\mathrm{t})-$ Kas dan Setara Kas (t-1)

CFO (Cash Flow Operation) $(\mathrm{t}-1)=$ Arus kas operasi sebelum tahun t-1

$\mathrm{CFO}($ Cash Flow Operation $)(\mathrm{t})=$ Arus kas operasi pada tahun $\mathrm{t}$

CFO (Cash Flow Operation) $(t+1)=$ Arus kas operasi setelah tahun $\mathrm{t}+1$

$\triangle$ REV $($ Revenue $)=$ Perubahan pendapatan

$\triangle \mathrm{REV}=$ Pendapatan pada tahun $(\mathrm{t})-$ Pendapatan sebelumnya (t-1)

PPE (Property, Plan, and Equipment $)=$ Aset tetap

Setelah didapatkan nilai TCA, CFO, REV dan PPE maka seluruh nilai tersebut dibagi dengan total aset perusahaan. Variabel kualitas akrual pada model utama hipotesis penelitian adalah standar deviasi dari nilai residual (error) persamaan tersebut di atas. Untuk memastikan kualitas akrual dapat dinilai dengan baik, maka standar deviasi dari residual regresi persamaan untuk perusahaan i akan diperoleh dari t-2 sampai t (Suganda dan Syarif, 2015).

\section{Persistensi Laba}

Laba yang persisten merupakan laba yang cenderung tidak berfluktuatif dan mencerminkan keberlanjutan laba di masa depan dan berkesinambungan untuk periode yang lama (Fitriana dan Fadhlia, 2016). Persistensi laba akuntansi diukur menggunakan koefisien regresi antara laba akuntansi periode sekarang dengan laba akuntansi periode yang lalu. Skala data yang digunakan adalah rasio, dengan rumus (Putri dan Supadmi, 2016):

$$
\text { Eit }=\beta 0+\beta 1 \text { Eit }-1+\varepsilon \text { it }
$$

Keterangan:

Eit : laba akuntansi (earnings) setelah pajak perusahaan i pada tahun $\mathrm{t}$

Eit-1 : laba akuntansi (earnings) setelah pajak perusahaan i sebelum tahun $\mathrm{t}$

B0 : konstanta

$\beta 1 \quad$ : persistensi laba akuntansi

Apabila persistensi laba akuntansi $(\beta 1)>1$ hal ini menunjukkan bahwa laba perusahaan adalah high persisten. Apabila persistensi laba $(\beta 1)>$ 0 hal ini menunjukkan bahwa laba perusahaan tersebut persisten. Sebaliknya, persistensi laba $(\beta 1) \leq 0$ berarti laba perusahaan fluktuatif dan tidak persisten.

\section{Perataan Laba}

Perataan laba adalah cara yang digunakan manajemen untuk mengurangi fluktuasi laba yang dilaporkan agar sesuai dengan target yang diinginkan perusahaan. Praktik perataan laba terkait erat dengan manajemen laba, yaitu praktik manajemen laba dipengaruhi oleh konflik kepentingan antara manajemen (agent) dan pemilik (principal) ketika semua pihak berusaha untuk mencapai dan mempertahankan tingkat kemakmuran yang dikehendakinya. Perataan laba dihitung menggunakan indeks eckel (Kustono, 2010): 
Indeks Perataan Laba (IPL) $=\frac{C V \triangle S}{C V \triangle I}$

Di mana:

CV : Koefisien variasi dari variabel, yaitu standar deviasi dari perubahan laba dan perubahan penjualan dibagi dengan nilai yang diharapkan dari perubahan laba (I) dan perubahan penjualan (S).

$\Delta \mathrm{S}$ : Perubahan penjualan yang terjadi dalam satu periode.

$\Delta \mathrm{I}$ : Perubahan laba yang terjadi dalam satu periode.

Untuk menghitung $\mathrm{CV} \Delta \mathrm{I}$ atau $\mathrm{CV} \Delta \mathrm{S}$ dapat digunakan rumus:

$$
\mathrm{CV} \Delta \mathrm{I} \text { atau } \mathrm{CV} \Delta \mathrm{S}=\frac{\sqrt{\sum(\Delta x-\Delta x)^{2}}}{n-1}: \Delta \mathrm{x}
$$

Keterangan:

$\Delta \mathrm{x}$ : perubahan laba (I) atau penjualan (S) antara tahun $\mathrm{n}$ dengan $\mathrm{n}-1$

$\Delta \mathrm{x}$ : rata-rata perubahan laba (I) atau penjualan (S) antara tahun $\mathrm{n}$ dengan $\mathrm{n}-1$

$\mathrm{n}$ : banyaknya tahun yang diamati.

Mengacu pada pendapat Syahriana (2006) dalam Rahmawati (2012), apabila CV $\Delta \mathrm{S}>\mathrm{CV} \Delta \mathrm{I}$, maka perusahaan digolongkan sebagai perusahaan yang melakukan tindakan perataan laba atau dengan kata lain perusahaan tersebut memiliki indeks perataan laba lebih dari 1 (IPL > 1).

\section{Informasi Asimetri}

Variabel dependen yang digunakan dalam penelitian ini adalah informasi asimetri. Apriliani (2012) dalam Husna dan Zulfikar (2017) mengemukakan bahwa informasi asimetri merupakan suatu keadaan dimana manajer memiliki akses informasi atas prospek perusahaan yang tidak dimiliki oleh pihak luar perusahaan. Pengukuran informasi asimetri yang digunakan dalam penelitian ini adalah bid-ask spread.

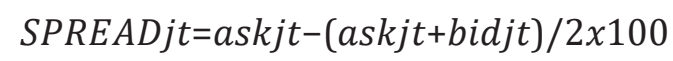

Keterangan:

Askjt $=$ harga permintaan tertinggi saham perusahaan $\mathrm{j}$ yang terjadi hari $\mathrm{t}$.

Bidjt $=$ harga penawaran terendah saham perusahaan $\mathrm{j}$ yang terjadi pada hari $\mathrm{t}$.

\section{HASIL}

\section{Gambaran Umum Objek Penelitian}

Penelitian menggunakan populasi perusahaan manufaktur subsektor tekstil dan garment yang terdaftar di Bursa Efek Indonesia pada tahun 2011 - 2015. Data diperoleh melalui situs website www.idx.co.id dan https://finance.yahoo.com. Tujuan penelitian ini adalah untuk memahami mengenai pengaruh analisis laporan keuangan terhadap informasi asimetri.

Berdasarkan kriteria yang telah ditetapkan menggunakan metode purposive sampling, jumlah perusahaan yang diperoleh dan dijadikan sampel dalam penelitian ini adalah 9 perusahaan dengan total observasi 45 laporan keuangan perusahaan. Berikut nama-nama perusahaan yang menjadi sampel penelitian ini.

Tabel 2. Daftar Perusahaan Manufaktur Subsektor Tekstil dan Garment yang Menjadi Sampel Penelitian

\begin{tabular}{ccl}
\hline No & Kode & \multicolumn{1}{c}{ Nama Perusahaan } \\
\hline 1 & ADMG & PT Polychem Indonesia Tbk \\
2 & ERTX & PT Eratex Djaja Tbk \\
3 & ESTI & PT Ever Shine Tex Tbk \\
4 & INDR & PT Indo-Rama Synthethics Tbk \\
5 & PBRX & PT Pan Brothers Tbk \\
6 & POLY & PT Asia Pacific Fiber Tbk \\
7 & SSTM & PT Sunson Textile Manufacturer Tbk \\
8 & STAR & PT Star Petrochem Tbk \\
9 & UNIT & PT Nusantara Inti Corpora Tbk \\
\hline
\end{tabular}

Sumber: Bursa Efek Indonesia, 2017

\section{Teknik Analisis Data}

\section{Statistik Deskriptif}

Hasil uji statistik deskriptif untuk variabel independen dan variabel dependen dapat dilihat pada Tabel 3.

Tabel 3. Statistik Deskriptif

\begin{tabular}{lccccc}
\hline & \multicolumn{4}{c}{ INFOAS AKRUAL PERSIS PERATA } \\
\hline Mean & 2.340444 & 0.355760 & 0.001433 & 9.863332 \\
Median & 0.980000 & 0.077890 & -0.001800 & 6.110520 \\
Maximum & 20.05000 & 10.02491 & 0.082060 & 42.27906 \\
Minimum & -0.480000 & 0.004400 & -0.070610 & 1.119930 \\
Std. Dev. & 3.883621 & 1.507497 & 0.022186 & 9.660623 \\
Skewness & 2.743935 & 6.097361 & 1.240381 & 1.893653 \\
Kurtosis & 11.65971 & 39.38810 & 9.868755 & 5.697633 \\
Jarque-Bera & 197.0760 & 2761.509 & 100.0012 & 40.53919 \\
Probability & 0.000000 & 0.000000 & 0.000000 & 0.000000 \\
Sum & 105.3200 & 16.00919 & 0.064490 & 443.8499 \\
Sum Sq. Dev. & 663.6306 & 99.99214 & 0.021658 & 4106.416 \\
Observations & 45 & 45 & 45 & 45 \\
\hline
\end{tabular}


Kesimpulan dari analisis statistik deskriptif nilai rata-rata atas seluruh variabel lebih kecil dari standar deviasi sehingga dapat diidentifikasi bahwa standar eror dari variabel tersebut besar.

\section{Uji Normalitas Data}

Hasil uji normalitas data untuk variabel independen dan variabel dependen dapat dilihat pada Gambar 1.

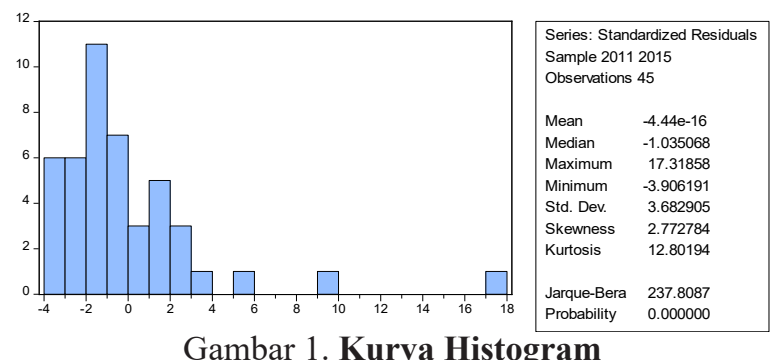

Dilihat dari Gambar 1 terlihat bahwa probability 0,00000 yang berarti bahwa data berdistribusi tidak normal.

\section{Analisis Regresi Data Panel}

Di dalam menganalisis data panel, terdapat tiga model regresi berganda yang perlu dipilih yang paling cocok dengan data yang diteliti, yaitu Common Effect Model, Fixed Effect Model dan Random Effect Model. Pertama-tama penulis melakukan uji chow, untuk memilih antara Common Effect Model dengan Fixed Effect Model mana yang lebih sesuai dijadikan model penelitian. Berikut ditampilkan dalam Tabel 4 kesimpulan uji pemilihan model.

Tabel 4. Kesimpulan Uji Pemilihan Model

\begin{tabular}{lcc}
\hline \multicolumn{1}{c}{ Jenis Uji } & $\begin{array}{c}\text { Perbandingan } \\
\text { Model }\end{array}$ & Model Terpilih \\
\hline Uji Chow & CEM vs FEM & FEM \\
Uji Hausman & REM vs FEM & FEM \\
\hline
\end{tabular}

Kesimpulan dari uji pemilihan model seperti yang dijabarkan pada tabel 4, model analisis regresi yang paling cocok untuk penelitian ini adalah Fixed Effect Model.

\section{Uji Asumsi Klasik \\ Uji Multikolonieritas}

Hasil uji multikolonieritas untuk variabel independen dan variabel dependen dapat dilihat pada Tabel 5.

\section{Tabel 5. Uji Multikolonieritas}

Variance Inflation Factors

Date: 08/14/20 Time: 23:29

Sample: 145

Included observations: 45

\begin{tabular}{cccc}
\hline Variable & $\begin{array}{c}\text { Coefficient } \\
\text { Variance }\end{array}$ & $\begin{array}{c}\text { Uncentered } \\
\text { VIF }\end{array}$ & $\begin{array}{c}\text { Centered } \\
\text { VIF }\end{array}$ \\
\hline & & & \\
C & 0.801311 & 2.477215 & NA \\
AKRUAL & 0.209682 & 1.522423 & 1.440380 \\
PERSIS & 950.3743 & 1.420105 & 1.414070 \\
PERATA & 0.003863 & 2.251694 & 1.089830 \\
\hline Sumber: Data Diolah Penulis Menggunakan E-Views 8
\end{tabular}

Berdasarkan tabel 5 dapat dilihat bahwa nilai centered VIF untuk variabel AKRUAL, PERSIS, PERATA seluruhnya dibawah 10 dan diatas 0,10 maka dapat diartikan bahwa tidak terdapat multikolonieritas pada penelitian ini.

\section{Uji Heterokedastisitas}

Hasil uji heterokedastisitas untuk variabel independen dan variabel dependen dapat dilihat pada Tabel 6.

\section{Tabel 6. Uji Heterokedastisitas}

Heteroskedasticity Test: White

\begin{tabular}{llll}
\hline $\begin{array}{l}\text { F-statistic } \\
\text { Obs*R- }\end{array}$ & 0.497661 & Prob. F(9,35) & 0.8659 \\
$\begin{array}{l}\text { squared } \\
\begin{array}{l}\text { Scaled } \\
\text { explained SS }\end{array}\end{array}$ & $\begin{array}{l}\text { 25.00857 } \\
\text { 25 }\end{array}$ & Prob. Chi-Square(9) & 0.8250 \\
& & Pquare(9) & 0.0030
\end{tabular}

Uji heterokedastisitas dalam penelitian ini menggunakan uji white, dengan hasil sesuai dengan tabel 6, probabilitas untuk variabel AKRUAL, PERSIS, dan PERATA seluruhnya diatas 0,05 maka dapat disimpulkan tidak terdapat heterokedastisitas dalam penelitian ini.

\section{Pengujian Hipotesis}

Hasil uji hipotesis dengan analisis regresi berganda dapat dilihat pada Tabel 7 .

\section{Tabel 7. Hasil Analisis Regresi Berganda}

Dependent Variable: INFOAS

Method: Panel Least Squares

Date: 08/14/20 Time: 23:07

Sample: 20112015

Periods included: 5

Cross-sections included: 9

Total panel (balanced) observations: 45 


\begin{tabular}{|c|c|c|c|}
\hline Variable & Coefficient & $\begin{array}{l}\text { Std. } \\
\text { Error t-Statistic }\end{array}$ & Prob. \\
\hline $\mathrm{C}$ & 3.767634 & 0.5045177 .467802 & 0.0000 \\
\hline AKRUAL & -0.437885 & $0.269707-1.623555$ & 0.1140 \\
\hline PERSIS & -32.04136 & $17.21369-1.861388$ & 0.0716 \\
\hline PERATA & -0.124247 & $0.038052-3$ & 0.0026 \\
\hline \multicolumn{4}{|c|}{ Effects Specification } \\
\hline \multicolumn{4}{|c|}{ Cross-section fixed (dummy variables) } \\
\hline R-squared & 0.832353 & Mean dependent var & 2.340444 \\
\hline $\begin{array}{l}\text { Adjusted } \\
\text { R-squared }\end{array}$ & 0.776471 & S.D. dependent var & 3.883621 \\
\hline $\begin{array}{l}\text { S.E. of } \\
\text { regression }\end{array}$ & 1.836131 & $\begin{array}{l}\text { Akaike info } \\
\text { criterion }\end{array}$ & 4.276376 \\
\hline $\begin{array}{l}\text { Sum squared } \\
\text { resid }\end{array}$ & 111.2554 & Schwarz criterion & 4.758153 \\
\hline $\begin{array}{l}\text { Log } \\
\text { likelihood }\end{array}$ & -84.21847 & $\begin{array}{l}\text { Hannan-Quinn } \\
\text { criter. }\end{array}$ & 4.455978 \\
\hline F-statistic & 14.89479 & Durbin-Watson stat & 1.860901 \\
\hline $\begin{array}{l}\text { Prob(F- } \\
\text { statistic) }\end{array}$ & 0.000000 & & \\
\hline
\end{tabular}

Berdasarkan tabel 7 hasil analisis regresi berganda menunjukkan bahwa nilai probabilitas kualitas akrual $0,1140>0,05$, hal ini berarti bahwa variabel kualitas akrual tidak berpengaruh terhadap informasi asimetri, nilai probabilitas persistensi laba $0,0716>0,05$, hal ini berarti bahwa variabel persistensi laba tidak berpengaruh terhadap informasi asimetri, nilai probabilitas perataan laba $0,0026<0,05$, hal ini berarti bahwa variabel perataan laba berpengaruh terhadap informasi asimetri.

Persamaan regresi yang dihasilkan adalah sebagai berikut:

$\mathrm{Y}=-$ 0,437885AKRUAL $-32,04136$ PERSIS0,124247 PERATA $+3,767634$

\section{Koefisien Determinasi}

Berdasarkan tabel 7 dapat dilihat nilai R-Squared sebesar 0,832353, hal ini menunjukkan bahwa variabel dependen dapat dijelaskan oleh variabel independen yang diteliti sebanyak $83,23 \%$, dan sisanya dijelaskan oleh variabel lain yang tidak diteliti oleh penulis.

\section{PEMBAHASAN}

Berdasarkan pengujian regresi berganda yang sudah dijelaskan pada bagian sebelumnya, interpretasi hasil dari pengujian dijelaskan sebagai berikut:

\section{Pengaruh Kualitas Akrual Terhadap Informasi Asimetri}

Berdasarkan Tabel 7, variabel kualitas akrual menunjukkan koefisien regresi negatif sebesar 0,437885 . Probabilitas menunjukkan nilai yang lebih besar dari $\alpha=5 \%$, yaitu 0,1140 , sehingga hipotesis ke-1 tidak berhasil didukung atau $\mathrm{H} 0$ diterima. Penilitian ini berhasil membuktikan bahwa kualitas akrual tidak berpengaruh terhadap informasi asimetri. Hal ini menunjukkan bahwa kualitas akrual perusahaan yang dibuat untuk mencatat informasi keuangan yang aktivitasnya terjadi pada periode berjalan namun transaksinya terjadi pada periode yang akan datang, tidak berpengaruh signifikan dengan kemungkinan terjadinya informasi asimetri pada perusahaan.

Hasil penelitian ini mendukung hasil penelitian dari Husna dan Zulfikar (2016) yang menyatakan kualitas akrual tidak berpengaruh terhadap informasi asimetri dan tidak sejalan dengan hasil dari penelitian Apriliani (2012) yang memiliki hasil pelaporan keuangan berbasis akuntansi memiliki pengaruh signifikan terhadap informasi asimetri.

\section{Pengaruh Persistensi Laba Terhadap Informasi Asimetri}

Berdasarkan Tabel 7, variabel persistensi laba menunjukkan koefisien regresi negatif sebesar 32,04136 dan probabilitas menunjukkan nilai yang lebih kecil dari $\alpha=5 \%$, yaitu 0,0716 , sehingga hipotesis ke-2 tidak berhasil didukung atau $\mathrm{H} 0$ diterima. Penilitian ini berhasil membuktikan bahwa persistensi laba tidak berpengaruh terhadap informasi asimetri. Hal ini menunjukkan bahwa laba perusahaan yang persisten dan tidak berfluktuasi secara signifikan menjadi salah satu pemicu terjadinya informasi asimetri.

Hasil penelitian ini tidak mendukung hasil penelitian dari Apriliani (2012), Husna dan Zulfikar (2016) yang menyatakan persistensi laba berpengaruh terhadap informasi asimetri.

\section{Pengaruh Perataan Laba Terhadap Informasi Asimetri}

Berdasarkan Tabel 7, variabel perataan laba menunjukkan koefisien regresi negatif sebesar 0,124247 dan probabilitas menunjukkan nilai yang lebih kecil dari $\alpha=5 \%$ yaitu 0,0026 , sehingga hipotesis ke-4 berhasil didukung atau $\mathrm{H} 0$ ditolak. Hal ini menunjukkan bahwa perataan laba yang dilakukan perusahaan dapat mempengaruhi kemungkinan terjadinya informasi asimetri. 
Hasil penelitian ini mendukung hasil penelitian dari Apriliani (2012), Husna dan Zulfikar (2016) yang menyatakan perataan laba berpengaruh terhadap informasi asimetri.

\section{Pengaruh Kualitas Akrual, Persistensi Laba, dan Perataan Laba Terhadap Informasi Asimetri}

Berdasarkan Tabel 7 nilai Prob(F-Stat) sebesar 0,000000 lebih kecil dari nilai Ftabels sebesar 3,41. Maka dapat diambil kesimpulan bahwa secara bersama-sama variabel independen memiliki pengaruh namun sangat lemah dan tidak dapat digunakan untuk memprediksi terjadinya informasi asimetri secara bersama-sama.

Hasil penelitian ini tidak mendukung hasil penelitian Fanani (2009) dan Apriliani (2012) yang menyatakan bahwa kualitas pelaporan keuangan memiliki pengaruh terhadap informasi asimetri.

\section{SIMPULAN}

Variabel kualitas akrual dan persistensi laba tidak memiliki pengaruh yang signifikan terhadap informasi asimetri. Sedangkan perataan laba berpengaruh negatif signifikan terhadap informasi asimetri. Hal ini berarti semakin kecil perusahaan melakukan perataan laba semakin besar kemungkinan adanya informasi asimetri.

Penelitian ini terbatas hanya pada variabel independen terkait atribut kualitas laporan keuangan berbasis akuntansi yaitu: kualitas akrual, persistensi laba dan perataan laba. Dalam penelitian ini tidak dibahas fungsi komite audit sebagai perantara antara pemegang saham dengan manajemen yang menjalankan perusahaan, di mana komite audit seharusnya memiliki peran dalam mencegah terjadinya informasi asimetri.

Data yang digunakan merupakan data sekunder yang diambil dari Bursa Efek Indonesia tahun 2010-2015 di mana hanya sebatas perusahaan manufaktur subsektor tekstil dan garment, sehingga memiliki jumlah observasi yang sedikit. Interpretasi atas hasil dari penelitian ini belum didukung oleh jurnal-jurnal internasional, sehingga masih memerlukan banyak masukan dan kritik yang membangun dari para pembaca.

\section{PENGHARGAAN}

Keberhasilan penulis dalam menyelesaikan penelitian ini tidak terlepas dari bimbingan, arahan, doa, dan dukungan dari berbagai pihak. Untuk itu penulis mengucapkan terima kasih yang sebesar-besarnya kepada pihak-pihak yang terlibat. Penulis juga menyampaikan terima kasih kepada LPPM Universitas Pamulang yang telah ikut membiayai penelitian ini.

\section{DAFTAR PUSTAKA}

Apriliani, A. N. (2012). Kajian Kualitas Pelaporan Keuangan Second Order terhadap Asimetri Informasi. Accounting Analysis Journal 1 (1). Semarang: Universitas Negeri Semarang.

Benardi et al. (2009). Faktor-faktor yang Mempengaruhi Luas Pengungkapan dan Implikasinya Terhadap Asimetri Informasi. Jurnal Akuntansi Keuangan dan Pasar Modal.

Fanani, Z. (2009). Kualitas Pelaporan Keuangan: Berbagai Faktor Penentu dan Konsekuensi Ekonomis. Jurnal Akuntansi dan Keuangan Indonesia. 6: 20-45.

Fitriyana, N. dan Fadhlia, W. (2016). Pengaruh Tingkat Hutang dan Arus Kas Akrual Terhadap Persistensi Laba (Studi Pada Perusahaan Property and Real Estate yang Terdaftar di Bursa Efek Indonesia Tahun 2010-2014. Jurnal Ilmiah Mahasiswa Ekonomi Akuntansi (JIMA) Vol. 1 No. 1. Banda Aceh.

Francis, J. R. et. al. (2004). Costs of Equity and Earnings Attributes, The Accounting Review 79: 967-1010.

Husna, Z. A. dan Zulfikar. (2017). Pengaruh Atribut Kualitas Pelaporan Keuangan Terhadap Informasi Asimetri pada Perusahaan Syariah yang Terdaftar di Jakarta Islamic Index pada Periode 2012-2015. Jurnal Peran Profesi Akuntansi Dalam Penanggulangan Korupsi. Surakarta.

Indriani, R. dan Khoiriyah, W. (2010). Pengaruh Kualitas Pelaporan Keuangan Terhadap Informasi Asimetri. Simposium Nasional Akuntansi XIII. Purwokerto.

Kusuma, et al. (2014). Pengaruh Kualitas Pelaporan Keuangan, Kepemilikan Institusional dan Ukuran Perusahaan Terhadap Asimetri Informasi pada Perusahaan Perbankan yang Terdaftar di BEI Tahun 2008-2012. Jurnal Akuntansi Fakultas Ekonomi Universitas Riau.

Purwanti, T. (2011). Analisis Pengaruh Volatilitas Arus Kas, Besaran Akrual, Votalitas Penjualan, Leverage, Siklus Operasi, Ukuran Perusahaan, Umur Perusahaan dan Likuiditas Terhadap Kualitas Laba. Tesis Fakultas Ekonomi Universitas Sebelas Maret. Surakarta. 
Setiany, E. dan Wulandari, A. (2015). Kualitas Pelaporan Keuangan dan Asimetri Informasi di Industri Manufaktur Indonesia. Efektif Jurnal Bisnis dan Ekonomi Vol 6 No. 2 Desember 2015 17-24.

Setyaningtyas, I. dan Hadiprajito, B. (2014). Analisis Faktor-faktor yang Mempengaruhi Perataan Laba (Income Smoothing). Diponegoro Journal of Accounting Volume 03, Nomor 02, Tahun 2014, 1-10.

Sugiyono. (2014). Metode Penelitian Administrasi. Bandung: Alfabeta.

Suwardjono. (2010). Teori Akuntansi Perekayasaan Pelaporan Keuangan, Edisi Ketiga, BPFE. Yogyakarta.
Triningtyas, I. Adan Siregar S.(2014). Pengaruh Kualitas Akrual Terhadap Biaya Utang dan Biaya Ekuitas (Studi Empiris pada Perusahaan yang Terdaftar di Bursa Efek Indonesia). Simposium Nasional Akuntansi ke 17. Mataram.

Ujiyantho, A. (2007). Asimetri Informasi dan Manajemen Laba suatu Tinjauan dalam Hubungan Keagenan. Jurnal Riset Akuntansi Indonesia.

Wijaya et al. (2010). Pengaruh Kualitas Akrual dan Leverage Terhadap Cash Holding Perusahaan. Jurnal Akuntansi dan Keuangan Indonesia, Desember 2010, Volume 7 - No. 2 170-186.

www.bisnis.liputan6.com

www.idx.co.id 